\title{
How Safe is Dabigatran in Elderly?
}

\section{Yaşlı Hastalarda Dabigatran Kullanımı ne kadar Güvenli?}

\section{Kamile Silay ${ }^{1}$, Sema Akinci ${ }^{2}$, Arife Ulas ${ }^{3}$, Ahmet Yalcin ${ }^{4}$}

${ }^{1}$ Yildirim Beyazit University, Faculty of Medicine, Ataturk Training and Research Hospital, Department of Geriatrics, Ankara, Turkey

${ }^{2}$ Ataturk Training and Research Hospital, Department of Hematology, Ankara, Turkey

${ }^{3}$ Ataturk Training and Research Hospital, Department of Medical Oncology, Ankara, Turkey

${ }^{4}$ Ataturk Training and Research Hospital, Department of Geriatrics, Ankara, Turkey

\begin{abstract}
The aim is to report a case of dabigatran induced gastrointestinal bleeding without any obvious source and emphasize the risk of drug interaction in an elderly patient. An 87 year-old female who was treated with dabigatran and nifedipine for nonvalvular atrial fibrillation developed gastrointestinal bleeding. Endoscopy and colonoscopy was performed and no pathology was identified. Bleeding stopped spontaneously. Our case suggests that drug interactions may increase the risk of bleeding additional to old age in patients who are treated with dabigatran. Clinicians should use these medications with caution in geriatric population particularly over 85 years old.
\end{abstract}

Key Words: Dabigatran, elderly, bleeding, drug interaction

Received: 07.10.2015

Accepted: 06.03.2016

\section{ÖZET}

Burada Dabigatran kullanımı sırasındaki gastrointestinal kanama olgusu sunularak yaşlı hastalarda ilaç-ilaç etkileşim riskini vurgulamak amaçlanmıştır. Nonvalvüler atriyel fibrilasyon nedeni ile dabigatran ve nifedipin tedavisi alan 87 yaşındaki bayan hasta, gastrointestinal kanama şikayeti ile başvurmuştur. Yapılan endoskopi ve kolonoskopi sonucunda bir patoloji tespit edilememiştir. Kanama spontan olarak durmuştur. Vakamı dabigatran ile tedavi edilen hastalarda ileri yaşın yanısıra ilaç etkileşimlerinin de kanama riskini artırabileceğini göstermektedir. Klinisyenler bu ilaçları geriatrik populasyonda, özellikle 85 yaş üzerinde dikkatli bir şekilde kullanmalıdır.

Anahtar Sözcükler: Dabigatran, yaşlı, kanama, ilaç etkileşimi

Geliş Tarihi: 10.07.2015

Kabul Tarihi: 03.06.2016

\section{INTRODUCTION}

Dabigatran etexilate (DE) selectively and reversibly inhibits thrombin, producing a reliable and dose-dependent anticoagulant effect. Dabigatran provides an effective alternative therapy to warfarin since it does not require regular INR monitoring. It was approved by the FDA in 2010 to reduce the risk of stroke in patients with nonvalvular atrial fibrillation (NVAF) (1). Approximately $80 \%$ of dabigatran is excreted renally and requires dosage reductions for patients with reduced creatinine clearance (2). DE is a good alternate therapy to warfarin since it does not require routine monitoring; on the other hand, concerns associated with its use include the lack of a reversal agent, complex dose adjustments, and limited guidance to the management of drug interaction.
In the RE-LY (Randomized Evaluation of Long Term Anticoagulation Therapy) trial, patients with atrial fibrillation who took low-dose dabigatran (110 mg twice daily) had rates of stroke and systemic embolism that were similar to warfarin; however, dabigatran was associated with a lower risk of major bleeding at this dosage. When taken at the high dose $(150 \mathrm{mg}$ twice daily), dabigatran was associated with lower rates of stroke and systemic embolism, but similar rates of major bleeding when compared with warfarin (3).

Because up to $80 \%$ of dabigatran is eliminated via the kidneys, older individuals and those with renal impairment are more susceptible to adverse events (4).

Address for Correspondence / Yazışma Adresi: Kamile Silay, MD, Yildirim Beyazit University, Faculty of Medicine, Ataturk Training and Research Hospital Department of Internal Medicine and Geriatrics, Bilkent Ankara, Turkey E mail: kamilesilay@hotmail.com (C)Telif Hakkı 2016 Gazi Üniversitesi Tıp Fakültesi - Makale metnine http://medicaljournal.gazi.edu.tr/ web adresinden ulaşılabilir.

CCopyright 2016 by Gazi University Medical Faculty - Available on-line at web site http://medicaljournal.gazi.edu.tr/

doi:http://dx.doi.org/10.12996/gmj.2016.45 
Since 2011, dabigatran product information has added that renal function should be assessed at initiation of treatment and annually in patients older than 75 years or in those with a GFR of $<50 \mathrm{~mL} / \mathrm{min} / 1.73 \mathrm{~m}^{2}$ (1). In 2011, a total of 3,781 serious adverse events associated with dabigatran were reported to the US Food and Drug Administration; of these, 2,367 were reports of hemorrhage, and 542 cases had resulted in death (5).

There is no available reversal agent for dabigatran or laboratory testing to determine its degree of anticoagulation activity. Dabigatran prolongs markers of coagulation, such as the activated partial thromboplastin time (aPTT) and ecarin clotting time, and may potentially impact INR values. The ecarin clotting time is a more specific parameter to determine the effect of anticoagulation (6); however, most laboratories are not adequately equipped to perform the laboratory test.

In this article, we discussed a case of dabigatran-induced gastrointestinal (GI) bleeding in an elderly woman and emphasize the risk of drug interactions with dabigatran in geriatric population.

\section{CASE REPORT}

A 87-year-old woman admitted to the hospital with three days history of melena accompanying nausea and poor oral intake. The patient's past medical history was significant for hypertension, nonvalvular atrial fibrillation and recently diagnosed diabetes mellitus. Her medications were perindopril/indapamid, nifedipine, furosemide, repaglinide, and dabigatran. Two months prior to admission, she was switched from warfarin to dabigatran $110 \mathrm{mg}$ twice daily due to poor controlled INR. The patient stopped taking all her medications, including dabigatran, in the last three days since she was nauseated. She was complaining of black, tarry stools in the last three days. She had a profuse, large amount of stool in the morning of admission. At the admission she was afebrile, her blood pressure was 105/40, and her heart rate was 100.

A full blood count showed that hemoglobin (hb) level was $6.1 \mathrm{~g} / \mathrm{dL}$ (her last $\mathrm{hb}$ level was $13 \mathrm{~g} / \mathrm{dL}$ two months prior to admission) with normal platelet and leucocytes. Laboratory tests was normal, except for elevated urea nitrogen and creatinine, $82 \mathrm{mg} / \mathrm{dL}$ and $1.8 \mathrm{mg} / \mathrm{dL}$ (her baseline was $1.5 \mathrm{mg} / \mathrm{dL}$ ) respectively. Routine coagulation assays were prolonged (prothrombin time [PT], 25 seconds (range 12-18); INR was 2.0; activated partial thromboplastin time [APTT] was 53.3 seconds (range 25-40). Her oral intake was stopped and intravenous fluids and proton pump inhibitor infusion was initiated. She was transfused three packed red blood cells. The melena did not reoccur during her hospitalization. Her vitals stabilized and she underwent endoscopy the following morning which was normal. The following day colonoscopy was performed. No pathology was identified. Her creatinine level decreased to baseline, $1.5 \mathrm{mg} / \mathrm{dL}$ and PTT, PT and INR levels were decreased to 39.7, 19.2, and 1.45 respectively. The patient was discharged home in a stable condition with a hemoglobin level of $10.6 \mathrm{~g} / \mathrm{dL}$ after three days admission.

\section{DISCUSSION}

This case highlights the bleeding risk with dabigatran in an elderly patient, even within the recommended doses. Although the patient was receiving a reduced dose of dabigatran (110mg twice daily), based on her GFR (GFR=36 $\mathrm{mL} / \mathrm{min} / 1.73 \mathrm{~m}^{2}$ ), she had a hemorrhage without any obvious source. Application of the adverse drug reaction (ADR) probability scale of Naranjo in this case yielded a score of 7 , indicating a probable ADR caused by dabigatran.

The important point is the concomitant use of nifedipine which is among the medications that increases the concentration of dabigatran. The use of Pglycoprotein inhibitors and dabigatran in patients with severe renal impairment $(\mathrm{CrCl} 15-30 \mathrm{~mL} / \mathrm{min})$ should be avoided as per the drug information (1). Dabigatran is a prodrug that has a low bioavailability. This is partially due to its physicochemical properties and its absorption limiting transport out of enterocytes by P-glycoprotein (P-gp). The carboxylesterases hydrolyzes the prodrug to active dabigatran. Because only the prodrug dabigatran is a substrate for P-gp, its absorption can be altered by P-gp inducers or inhibitors. Although several drug interactions with dabigatran and P-glycoprotein inducers and inhibitors have been identified, it is unclear how to balance drug interactions without laboratory parameters to guide dosing adjustments $(7,8)$.
A recent study which evaluated the appropriateness of dabigatran use in 458 patients recommended monitoring of prescribing habits of dabigatran for patient safety. For appropriate use of oral anticoagulants; pharmacist interventions, therapeutic interchanges, and obtaining appropriate patient parameters are recommended (7).

The INR level was found elevated in our patient similar to previous case reports, even though the patient had not been exposed to vitamin $\mathrm{K}$ antagonists (9). We suggest monitoring PT and INR levels when using dabigatran in elderly patients.

In conclusion, this case suggests that drug interactions may increase the risk of bleeding additional to old age in patients who are treated with dabigatran. Larger prospective, well-controlled studies evaluating the safety of dabigatran use in the elderly should be considered. Clinicians should use these medications with caution in the geriatric population, particularly where over 85 years old.

\section{Conflict of interest}

No conflict of interest was declared by the authors

\section{REFERENCES}

1-Pradaxa (dabigatran etexilate mesylate) capsules [prescribing information] Ridgefield, CT: Boehringer Ingelheim Pharmaceuticals, Inc; September 2014. 2-Stangier J. Clinical pharmacokinetics and pharmacodynamics of the oral direct thrombin inhibitor dabigatran etexilate. Clin Pharmacokinet. 2008; 47: 285-95.

3-Connolly SJ, Ezekowitz MD, Yusuf S, et al; RE-LY Steering Committee and Investigators. Dabigatran versus warfarin in patients with atrial fibrillation [published correction appears in N Engl J Med. 2010;363:1877]. N Engl J Med. 2009; 361: 1139-51.

4-Stangier J, Rathgen K, Stähle H, Mazur D. Influence of renal impairment on the pharmacokinetics and pharmacodynamics of oral dabigatran etixilate: an open-label, parallel-group, single centre study. Clin Pharmacokinet. 2010; 49: 259-68.

5-Institute for Safe Medication Practices. Monitoring FDA MedWatch Reports: Anticoagulants the leading reported drug risk in 2011. www.ismp.org/QuarterWatch/pdfs/2011Q4.pdf. Published May 31, 2012.

6-Gosselin RC, Dwyre DM, Dager WE. Measuring dabigatran concentrations using a chromogenic ecarin clotting time assay. Ann Pharmacother. 2013;47: 1635-40.

7-Anastasia L. A., Katie S. Buehler, Sun H. Min, Margaret Riley, Michael W. Daly. Evaluation of Dabigatran for Appropriateness of Use and Bleeding Events in a Community Hospital Setting. Am Health Drug Benefits. 2014; 7: 376-84 8-Wittkowsky AK. Novel oral anticoagulants and their role in clinical practice. Pharmacotherapy. 2011; 31: 1175-1191.

9-Béné J1, Saïd W, Rannou M, Deheul S, Coupe P, Gautier S. Rectal bleeding and hemostatic disorders induced by dabigatran etexilate in 2 elderly patients. Ann Pharmacother. 2012;46: e14. 